\title{
Quinoa Mitigates Chlorfenapyr-Induced Testicular Toxicity in Rats
}

\author{
Nadia A.Hamed
}

\begin{abstract}
Chlorfenapyr (Chf), belongs to a new chemical class called halogenated pyrroles, used extensively in Egypt. Negative effects of pesticides on the male reproductive system have been shown broadly. In recent years, the use of medicinal herbs in reducing pesticide toxicity has increased worldwide; one of these herbals is Quinoa seeds (QS), contains high amount of protein, vitamins, and minerals. Our study evaluated the effects of QS on testicular toxicity in rats exposed to Chf. Twenty rats were divided into four groups; group (I) as control was fed on basal diet only, group (II) QS at $30 \%$ from the basal diet, group (III) $180 \mathrm{mg} / \mathrm{kg} \mathrm{b.w} /$ day of Chf, was fed on basal diet only and group (IV) Chf at $180 \mathrm{mg} / \mathrm{kg} \mathrm{b.w/day} \mathrm{plus} \mathrm{QS} \mathrm{at}$ $30 \%$ from the basal diet, the experimental period was four weeks. Rats were sacrificed and blood serum, sperm, and sexual organs samples were collected for biochemical and histomorphological studies. Results revealed that Chf treated animals showed sagging testicles with increased the testis relative weights. This effect was associated with a decline in count, motility, and viability of sperms, and increased sperm abnormality, and a decrease in sex hormones level $(P<0.05)$. On the other hand, QS showed improvement in almost all estimated parameters and mitigated all the toxic effects of Chf, which was confirmed with the histological examination of the testis. So, we can encourage QS consumption as a clue for the toxicity and infertility problems revealed as a result of chlorfenapyr exposure.
\end{abstract} Quinoa.

Key words: Chlorfenapyr, Testicular toxicity, Rats,

\section{INTRODUCTION}

Insecticides are chemicals used for controlling pests on plants or animals and may have bio pharmacological effects such as inducing stress, imbalance of hormones and/or physiological effects and reproductive toxicity (Alaa-Eldin et al., 2017; Sleem et al., 2019; Khalaf et al., 2021).

Infertility is an important medical and social problem in the world as regards $15 \%$ of couples are infertile and $40 \%$ are infertile because of male factor infertility(Kumar, N.and Singh, 2015). Occupational exposures to pesticides could reduce the fertility of workers by targeting many cell types of the testis (ie, germ, Leydig, and Sertoli cells) and changing hormone levels via the hypothalamic-pituitary-gonadal axis (Queirozand Waissmann, 2006). Semen parameters may also be affected, resulting in a decrease in sperm health and/or function. Studies concerning the causal link between pesticide exposure and reproductive impairment have increased in the literature in the past two decades (Farag et al., 2007; Ahmad et al., 2012; Lonare et al., 2016; Babazadehand Najafi, 2017; Sleem et al., 2019). Chlorfenapyr (Chf) is a new broadspectrum insecticide and acaricide. It was developed by structural modification of a microbial natural product, dioxapyrrolomycin (Addor et al., 1992) and is considered as the first commercial pesticide to be derived from a class halogenated pyrroles (Treacy et al., 1994). It has been widely used for agricultural pest control since 1995 as insecticide and miticide on cotton, ornamentals, and some vegetable and fruits crops (Rand, 2004; Sdeek et al., 2016; Badawy et al., 2020). Chlorfenapyr is relatively long environmental persistence and potential for acute lethal and reproductive toxicity in birds and possible aquatic toxicity (Albers et al., 2006). It is classified as a moderately hazardous pesticide but its toxicity in humans has rarely been studied (Kang et al., 2014; Han et al., 2019). Maternal and cytotoxic effects of Chf in pregnant female rats were studied and showed a significant decrease in the female body weight, in the metabolic parameters (as glucose, total protein, and cholesterol), and antioxidant biomarkers as superoxide dismutase (SOD), catalase (CAT), glutathione (GSH), and glutathione S-transferase (GST). Also, a significant elevation in the liver enzymes, urea, creatinine, and level of malondialdehyde (MDA) indicating oxidative stress was resulted (Sleem et al., 2019).

Recently, the protective effect against pesticide toxicity with medicinal plants, a plant-derived flavonoid present in foods, plant extract, and some vitamins became an important field of research (Saber et al., 2016; Choudhary et al., 2017; Shaheenand Yousafzai, 2017). Also, dietary change has increased consumer demand for healthy, fresh foods, so consumers are looking for natural, beneficial food items and a wellbalanced diet that need minimal time and effort for their preparation. Some cereals play a primary role in new lifestyles; to face consumer needs due to their physiological and metabolic advantage and their consumption has outspread from the breakfast list to any

DOI: 10.21608/asejaiqjsae.2021.177465

${ }^{1}$ Dept. of Mammalian and Aquatic Toxicology, Central Agricultural

Pesticides Laboratory (CAPL), Agricultural Research Center (ARC), Alexandria, Egypt

nadia010560@gmail.com 01005603031

Received April 30, 2021, Accepted, June 13, 2021. 
time of the day, one of these cereals is Quinoa (ElKewawyand Morsy, 2019).

Quinoa (Chenopodium quinoa Willd.), ancient seeds, is a basic food in pre-hispanic Andean communities, used not only as a food but also for medicinal reasons (Jancurová et al., 2009).

Previous studies observed that bioactive compounds of Quinoa have a protective effect against some chemical toxins or drug-induced hepatotoxicity, hypercholesterolemia, hyperuricemia, and oxidative stress induced by different factors (Paśko et al., 2010; Alghamdi, 2018; El-Kewawyand Morsy, 2019; Wahba et al., 2019). Also, quinoa plays an important role to overcome some nutritional problems such as celiac disease (CD) which is a longevity food intolerance to gluten (Hafez, L., 2018). Quinoa has been cultivated in Egypt since 2005, and is considered as one of the best vegetal protein sources, where, it has a high biological value equals to that of beef, and higher than those of white rice, wheat, and corn (Alghamdi, 2018). Also, it contains significant amounts of antioxidant phytochemicals, and vitamins such as vitamin E, C, B2, B6, and folic acid with relatively high amounts (Jancurová et al., 2009). Moreover, quinoa is considered as a good source for many minerals and trace elements, where it contains calcium, magnesium, copper, iron, zinc, and potassium (Vilcacundoand HernándezLedesma, 2017). The important role for quinoa in nutritional behavior has been emphasized, not only in developing countries but also in the developed world. Also, it could be considered as a strategic crop used to complement the diet in rural/marginal regions, where energy-protein malnutrition affects most of the population of the developing countries (Jancurová et al., 2009). Quinoa, as the "mother grain", represents an exotic and healthy rediscovery in the developed world (Valencia-Chamorro, 2003). As we care about the infertility problem, it is well known that, the correct balance of macronutrients (carbohydrates, proteins, and fats), micronutrients as vitamins (vitamin E, B12and folate), and trace elements such as zinc and various antioxidants essential and needed for male fertility (Paśko et al., 2010; Wahba et al., 2019). So, quinoa is considered as a good solution to improve reproductive health either for males or females and may help in infertility issues(Lutzand Bascuñán-Godoy, 2017).

Therefore, the current study aimed to evaluate the effect of daily consumption of quinoa on some testicular toxicity biomarkers that induced by chlorfenapyr, including reproductive organs weight, reproductive hormones levels, sperm characters, and testis histopathological examination.

\section{MATERIAL AND METHODS}

\section{Experimental Materials:}

Chlorfenapyr (Corps Top 24\% SC) was obtained from Agrimar Company for Commercial Agencies, Egypt. Quinoa seeds were purchased from CEDAR, Packed by Groupe PHONICIA Inc. Montreal, QC.H4S1T2.

\section{Experimental design:}

Male albino rats weighing $150 \quad-160 \mathrm{~g}$ were obtained from the Faculty of Medicine; Alexandria University, Egypt. The animals were allowed to acclimatize for two weeks before the initiation of the experiment under laboratory conditions ( $12 \mathrm{~h}$ light $/ 12$ h dark, $22-26{ }^{\circ} \mathrm{C}$., $50-70 \%$ humidity) in stainless steel cages and provided with a commercial basal diet and water ad libitum. Animals were divided into four groups, each of five rats, and orally treated over 28 days as the following: Group I: Rats were given a commercial basal diet and kept as control. Group II: Rats were given QS at 30\% from the basal diet. Group III: Rats were treated with Chf $180 \mathrm{mg} / \mathrm{kg}$ b.w which represents $1 / 3 \mathrm{LD}_{50}$ (Oral $\mathrm{LD}_{50}$ was $544.3 \mathrm{mg} / \mathrm{kg}$ b.w; according to Department of Mammalian Toxicology, Pesticide Central Laboratory, Agriculture Research Center) USEPA. (2001). Group IV: Rats were given Chf $180 \mathrm{mg} / \mathrm{kg}$ b.w plus QS at 30\% from the basal diet. Chlorfenapyr was orally administrated to animals by esophageal intubation. The body weights of control and treated animals were recorded weekly.

\section{Evaluation of relative reproductive organ weights:}

Final body weights (by the end of the experiment) were recorded and rats from all groups were sacrificed after anesthesia with diethyl ether and the reproductive organs (epididymus and testes) were taken to measure fertility indices and testicular biomarkers. The absolute weights of testes and epididymides were recorded then the relative weight was calculated as the ratio of tissue weight $(\mathrm{g})$ to body weight $(\mathrm{g})($ Relative organ weight $=$ Organ weight/final body weight $\times 100$ ).

\section{Evaluation of sperm parameters:}

The caudal epididymis of one testis was excised and placed in a Petri dish containing $2 \mathrm{ml}$ warm $0.9 \%$ $\mathrm{NaCl}$, and then, macerated by scissor to obtain the epididymal contents in a suspension that was handled exactly as the semen (Hafez, E., 1970). To determine sperm numbers, spermatozoa motility parameters, and sperm morphology, a computer-assisted semen analysis system (CASA System; MiniTüb, Germany) with Olympus microscope (Olympus, Tokyo, Japan) was used. 


\subsection{Assessment of spermatozoa :}

The count of sperm cells was determined as described by (Robb et al., 1978). $200 \mu \mathrm{L}$ of the semen were pipetted in a plastic tube containing $800 \mu \mathrm{L}$ of $(0.9 \% \mathrm{NaCl}+$ formalin) to kill spermatozoa. The resulting solution was mixed well, then, spermatozoa were counted in an improved hemocytometer counting chamber. The sperm count was expressed as sperm in millions/ml.

\subsection{Assessment of spermatozoa motility:}

This assay was carried out according to (Slott et al., 1991). A drop of the suspension was covered by a prewarmed glass cover slide and examined under high power $\mathrm{x} 40$ for evaluating the individual motility of spermatozoa and expressed as a percentage of motile spermatozoa.

\subsection{Assessment of spermatozoa viability:}

To determine the percentage of sperm viability, equal volume of epididymal sperm suspension was stained with Eosin-Nigrosin, then the mixture of stained sperm was smeared on the clean slides and examined under 40x lens of a light microscope. A total of 200 sperm cells were examined on each slide. Sperms with altered plasma membrane seemed to be pink and sperms with intact plasma membrane were not stained. Finally, the results were expressed in percentage (Ikpeme et al., 2007).

\subsection{Assessment of spermatozoa morphological abnormalities:}

Semen samples were fixed with Hancock's solution and stained with 1\% Eosin $\mathrm{Y}$ and 5\% Nigrosine. Morphological sperm abnormalities were evaluated by using an Olympus microscope. A total of 200 spermatozoa from each rat were examined and individually scored into normal or abnormal, the criteria chosen for head abnormality were; no hook, excessive hook, amorphous, pin, and short head. For the tail, some abnormalities were recorded; coiled flagellum, bent flagellum, bent flagellum tip, and total abnormality rates of spermatozoa were expressed as a percentage according to (Adamkovicova et al., 2016; Wang et al., 2016).

\section{Hormonal assay:}

Serum testosterone $(\mathrm{T})$, luteinizing hormones (LH) and follicle stimulating hormone (FSH) were assayed by ELISA Kits (Monobind, Inc. California, USA), based on the principle of competitive binding and according to the manufacturer's instructions.

\section{Histopathological analysis:}

Small pieces of testis tissues were isolated from all rats, gently rinsed with physiological saline solution $(0.9 \% \mathrm{NaCl})$ to remove blood and debris adhering to the tissues and then fixed in $10 \%$ neutral buffered formalin for $24 \mathrm{~h}$. The fixative was removed by washing through running tap water overnight. After dehydrating through a graded series of alcohols, the tissues were cleared in methyl benzoate, embedded in paraffin wax. Sections were cut at $6 \mu \mathrm{m}$ thickness and stained with Hematoxylin (Druryand Wallington, 1980) and counterstained with Eosin (dissolved in 95\% alcohol). After dehydration and clearing, sections were mounted with DPX and observed under a microscope.

\section{Statistical analysis:}

way analysis of variance (ANOVA) was used to analyze data followed by the

The present results were expressed as mean \pm standard error (SE). The one- Student-Newman-Keuls test. The standard for statistical significance was set at $\mathrm{p}$ $\leq 0.05$. These tests were performed using the computer CoStat program, version 6.400, Copyright (C) 19982008, CoHort Software.

\section{RESULTS AND DISCUSSION}

\section{Relative reproductive organ weights:}

During the experiment, there were no mortality or clinical signs of toxicity except emaciation and sagging testicles, the testes became in a slouched position, in the Chf treated animals in group (III) were noticed. Changes in testicular and epididymis weight are a valuable index of reproductive health and determined phenomena in toxicological studies for assessing toxicity (Sharma et al., 2014).

Data in Table (1) show that there was a significant increase $(p<0.05)$ in the relative testis weight $17.2 \%$, which reflected the sagging testicles, and decrease in the relative epididymis weight $10.5 \%$ in the group (III) comparing to the control group (I). Kumar, A. and Nagar (2014) studied the histomorphometric of testis in deltamethrin treated albino rats and found the increase in testis weight as the repeated doses of the pesticide in rats caused an edematous fluid accumulation between the tubules and focally at sites within some of the tubules. Both epididymal epithelial cells and spermatozoa in the lumen are targets for xenobiotics; such exposures can result in undesirable toxic effects (Alaa-Eldin et al., 2017; Khalaf et al., 2021). Epididymis requires continuous androgenic stimulation for their normal growth and functions. Reduction in the weight of epididymis reflects a decreased bioavailability and production of androgen which are revealed in the present study and that was consistent with findings of others(Chitra et al., 2011). 
Table 1. Relative reproductive organs weights of male rats administrated to Chlorfenapyr (180 $\mathrm{mg} / \mathrm{kg} \mathrm{b.w})$, Quinoa seeds (30\% of basal diet), and their combination for 28 days

\begin{tabular}{lll} 
& "RTW" $(\boldsymbol{\%})$ & "REW" $(\boldsymbol{\%})$ \\
Treatment group & & \\
\hline I (Control) & $1.22 \pm 0.008^{\mathrm{b}}$ & $0.38 \pm 0.003^{\mathrm{b}}$ \\
II(Quinoa) & $1.31 \pm 0.023^{\mathrm{b}}$ & $0.43 \pm 0.008^{\mathrm{a}}$ \\
III(Chlorfenapyr) & $1.43 \pm 0.021^{\mathrm{a}}$ & $0.34 \pm 0.011^{\mathrm{c}}$ \\
IV(Chlorfenapyr+ Quinoa) & $1.27 \pm 0.044^{\mathrm{b}}$ & $0.38 \pm 0.012^{\mathrm{b}}$ \\
\hline Valers
\end{tabular}

Values are expressed as means (5 rats) \pm standard error (SE)

Values in the same column with different letters are significantly different at $(\mathrm{p}<0.05)$.

"RTW" $(\%)$, relative testes weight $=($ Testes weight/Body weight $) \times 100$

"REW" $(\%)$, relative epididymis weight $=($ Epididymis weight/Body weight $) \times 100$

\section{Sperm parameters:}

\subsection{Sperm count:}

Sperm count is one of the most sensitive tests for spermatogenesis and it is highly correlated with fertility. Data in Figure (1) showed that treatment of rats with Chf, significantly $(p<0.05)$, reduced the total sperm count from $40.3 \times 10^{6}$ in the control group to $18.3 \times 10^{6}$ in the Chf treated animals (group III). Co-administration raised that value to $32 \times 10^{6}$ in group IV. Whereas animals in group II, consumed QS $30 \%$ of the basal diet, showed a significant increase $(p<0.05)$ in the sperm count $56.7 \times 10^{6}$ which was higher than the control group. Histological structure of the testes confirmed this; where group III testis sections revealed degeneration and atrophy in some of the somniferous tubules as well as shortening of the seminiferous epithelium associated with decreased count of cells of the spermatogenic series and low luminal spermatozoal concentration (Figure 6).

\subsection{Sperm motility:}

The assessment of sperm vitality is one of the basic elements of semen analysis and is especially important in samples, where many sperm are immotile, to distinguish between immotile dead sperm and immotile live sperm(El-Kashoury et al., 2010). Our results revealed that the Chf exposure significantly induced $(\mathrm{p}<$ $0.05)$ reduction in the sperm motility percentage $15.7 \%$ in group III compared with control $62.3 \%$ as shown in (Figure 1) .On the other hand, group IV animals showed enhancement in the motility percent compared to group III because of the consumption of QS. Group II animals represented a significantly higher value more than the control group, which reflects the effect of QS on fertility parameters. A decline in sperm motility after oral administration of $\mathrm{Chf}$ is may be due to androgen insufficiency which caused impairment in testicular functions by altering the activities of the enzymes responsible for spermatogenesis; this suggests an antiandrogenic effect of Chf (El-Kashoury et al., 2010; Sharma et al., 2014).

\subsection{Sperm viability:}

Figure (1) show a significant decrease in the percentage of live sperm (viable) in group III compared with the control and QS group, 6\%, where the obtained values were $55 \%$, and $55.3 \%$, respectively. While animals in group IV, co-administered QS, revealed a $25.3 \%$ viability percentage. All the results presented in Fig.1 (sperm count, motility, and viability) explained the important role of QS in fertility enhancement.

\subsection{Spermatozoa morphological abnormalities:}

Sperm morphology is a very strong indicator of a person's bodily and thus testicular health, which is strongly reacting to bodily, physiological, and environmental stresses, far more than any other organ (Menkveld et al., 2011). As shown in Fig. (2), the animals in group III represented a significant $(\mathrm{p}<0.05)$ reduction in normal sperm percentage, $16.6 \%$ compared with the control group, $62.3 \%$. While group IV showed a less significant reduction, $47 \%$, and group II revealed a significant increase in the normality percent, $78.3 \%$. The sperm malformation and abnormalities were showed in Fig. (3) included tail and head abnormalities such as bent flagellum tail, broken tail, and detached head. While the reduction in sex hormone levels affects the spermatogenesis process and development of seminiferous tubule, resulting in a low number of functional sperms and low fertility(Sharma et al., 2014), results in Fig. (4) had revealed a significant decrease in the sex hormones levels due to Chf treatment. These results go hand in hand with those of (Sharma et al., 2014; Saber et al., 2016; Khushboo et al., 2018) where the adverse effects of several pesticides on the reproductive organs and fertility of different experimental animals are documented. 

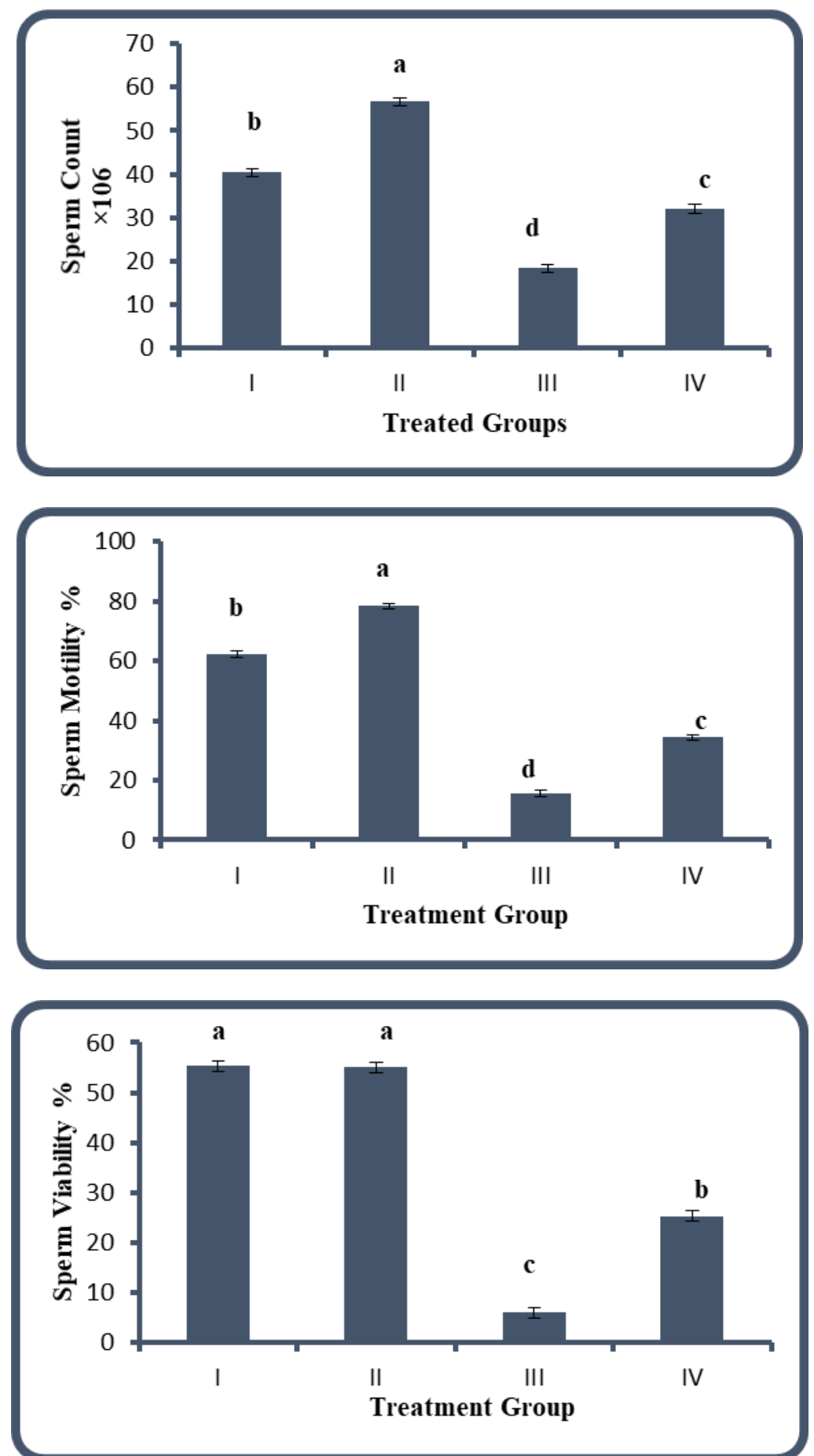

Fig. 1. Sperm count, sperm motility, sperm normality and sperm viability of adult albino rats exposed to Chlorfenapyr $(180 \mathrm{mg} / \mathrm{kg} \mathrm{b.w})$, Quinoa seeds (30\% of basal diet), and their combination for 28 days. Bars with the different letters are significantly different at $(p<0.05)$.Values are expressed as means $(5$ rats $) \pm$ standard error (SE) 


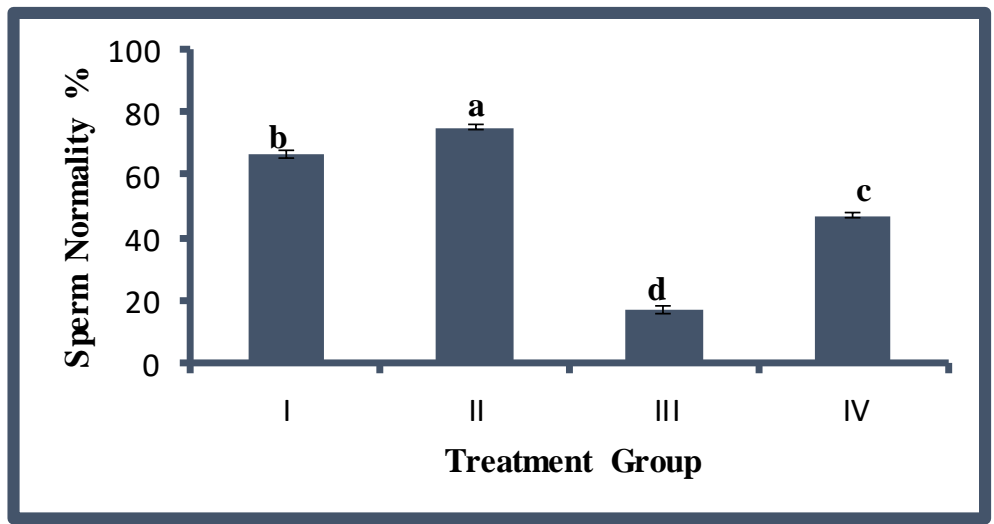

Fig. 2.Sperm normality percentage of adult albino rats exposed to Chlorfenapyr ( $180 \mathrm{mg} / \mathrm{kg} \mathrm{b.w})$, Quinoa seeds (30\% of basal diet), and their combination for 28 days. Bars with the different letters are significantly different at $(p<0.05)$. Values are expressed as means $(5$ rats $) \pm$ standard error $(\mathrm{SE})$
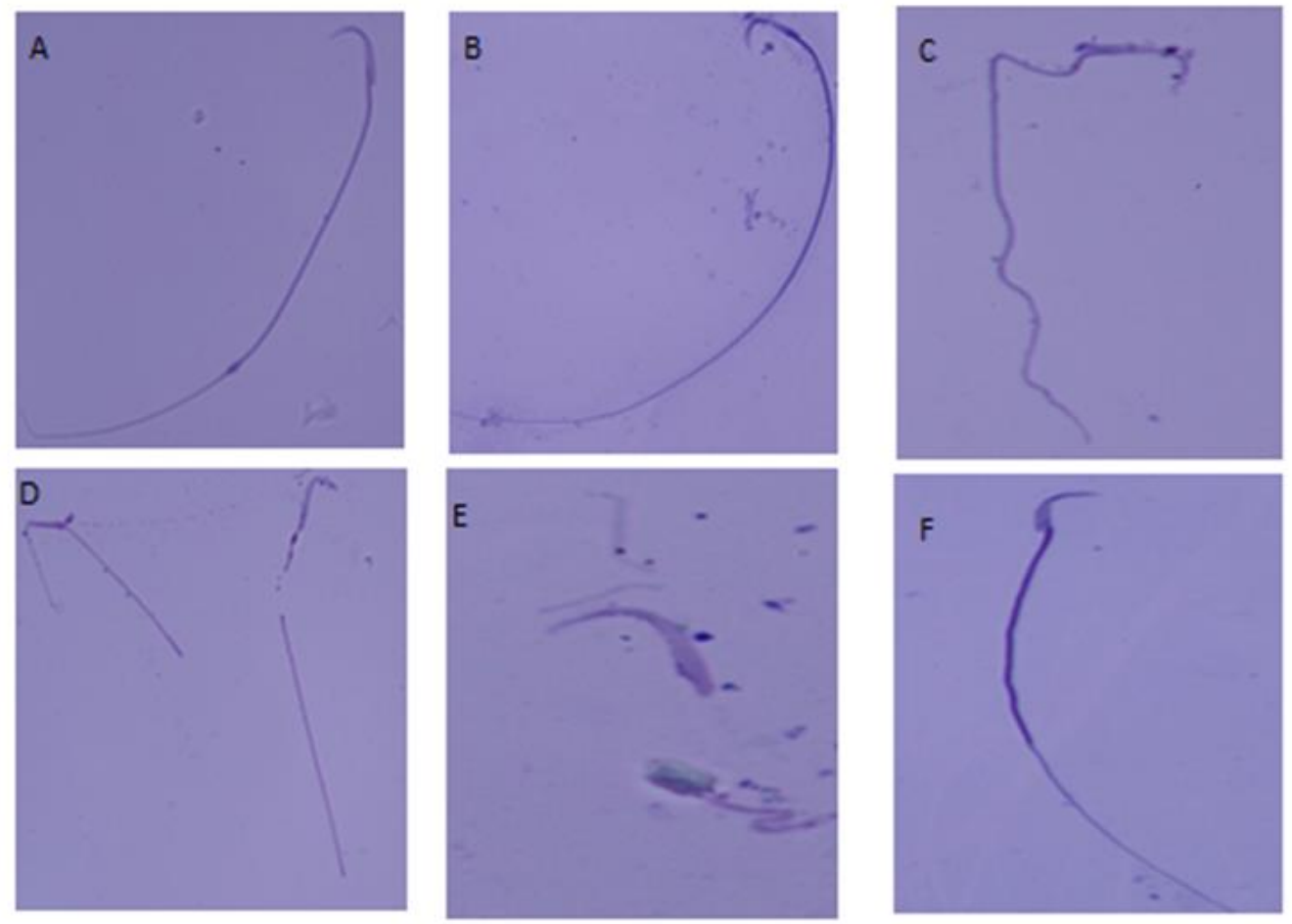

Fig. 3. Sperm morphological assessment illustrating normal sperm and various sperm defects. Normal sperm A, B as (group I and II), abnormal sperm tail and head morphology after chlorfenapyr exposure, bent flagellum C, broken tail D, and detached head E (group III). F (group IV) restored normal sperm morphology (eosin and nigrosine stains, $\mathrm{X} 400$ ) 


\section{Effect on sex hormones:}

Insecticides exert their toxic outcomes on the male reproductive system directly by affecting reproductive organs (testes, Sertoli cells, Leydig cells) and germ cells or impairing hormonal balance in the secondary endocrine system(Alaa-Eldin et al., 2017; Khalaf et al., 2021). Sexual and reproductive function in man is the result of neuroendocrine mechanisms involving hypothalamic, pituitary, and gonadal hormones. Testosterone, is one of the key regulators of spermatogenesis which promotes the switching of round spermatids into elongated spermatids, produced by the gonads in testicular Leydig cells, the rate of secretion of testosterone is enhanced by LH secreted by the anterior pituitary gland (El-Kashoury et al., 2010). FSH is the second key regulator of the spermatogenic process. Its receptors are present on the Sertoli cells. Both testosterone and FSH exert an initial stimulatory effect on the same germ cell type (El-Kashoury et al., 2010).

Relative to control, significant alterations in serum concentrations of FSH, LH, and testosterone are shown in Fig. (4). The rats in the Chf group had significantly $(p<0.05)$ lower FSH level by $75 \%$ and a significant increase in the QS group by $32 \%$, where combined $\mathrm{Chf}$ and QS revealed decreased value by $68 \%$. The levels of serum LH showed a decreasing tendency in (group III) by $70 \%$, while group II showed an enhancement by $21 \%$. Testosterone showed a significant decrease $(\mathrm{p}<0.05)$ in the Chf group by $44 \%$ and an increase in the QS group by $38 \%$, where the combined Chf and QS group almost equal to the control. The significant decrease of testosterone level may be as a result of direct damage of Chf on Leydig cells, which are the main site of testicular androgen biosynthesis. Reduction in testosterone as well FSH and LH suggest that apart from testicular tissue, Chf may also be affecting the hypothalamus-pituitary axis as inhibiting effective spermatogenesis and development of seminiferous tubule, resulting in a low number of functional sperms and low fertility (Fig.1). The reduction in testosterone and pituitary gonadotrophins (FSH and LH) secretions due to pesticide exposure have been previously reported (Sharma et al., 2014; Saber et al., 2016; Khushboo et al., 2018).

\section{Histopathological analysis:}

Testicular histopathology is considered the standard for measuring testicular injury. As shown in Fig. (5), the control and QS groups testis showed normal histological architecture with pathological free seminiferous tubule (ST); ordinary shape, their epithelium is structurally intact, spermatogonia $(\mathrm{Sg})$ and Sertoli cells $(\mathrm{SC})$ were resting on intact basement membrane (BM) in whirls. All the stages of spermatogenesis; round spermatids (RS), elongated spermatids (ES), late- stage sperms (S) were noticed, and lumens (L) of seminiferous tubules were filled with mature sperm. There were some enhancements and contrast in the overall parameters especially the concentration of mature sperms in the (L) in the QS group, which reflects the mentioned result in Fig. (1) and highlights the role of QS on fertility. On the other hand, the photomicrograph of the ST from rats in the group (III) which administered Chf (Fig.6. A-D) showed an irregular shape with dilatation and a wider luminal diameter, presented many exfoliated cells, reduced or loss of mature sperm cells, and increased interstitial spaces (Is). Leydig cells, which are responsible for testosterone production, were atrophied and that explained the reduced secreted level of testosterone in animals from group III. Disorganization in the germinal epithelium with disrupted BM and the $\mathrm{Sg}$ showed highly vacuolated cytoplasm splatted from the BM. Fig. 7 represents the testis histomorphology of animals in group (IV) and shows that QS restored and recuperated the histopathological changes produced by Chf exposure; most of the seminiferous tubules had attained ordinary structure with a resumption of complete spermatogenesis as in the control group. 

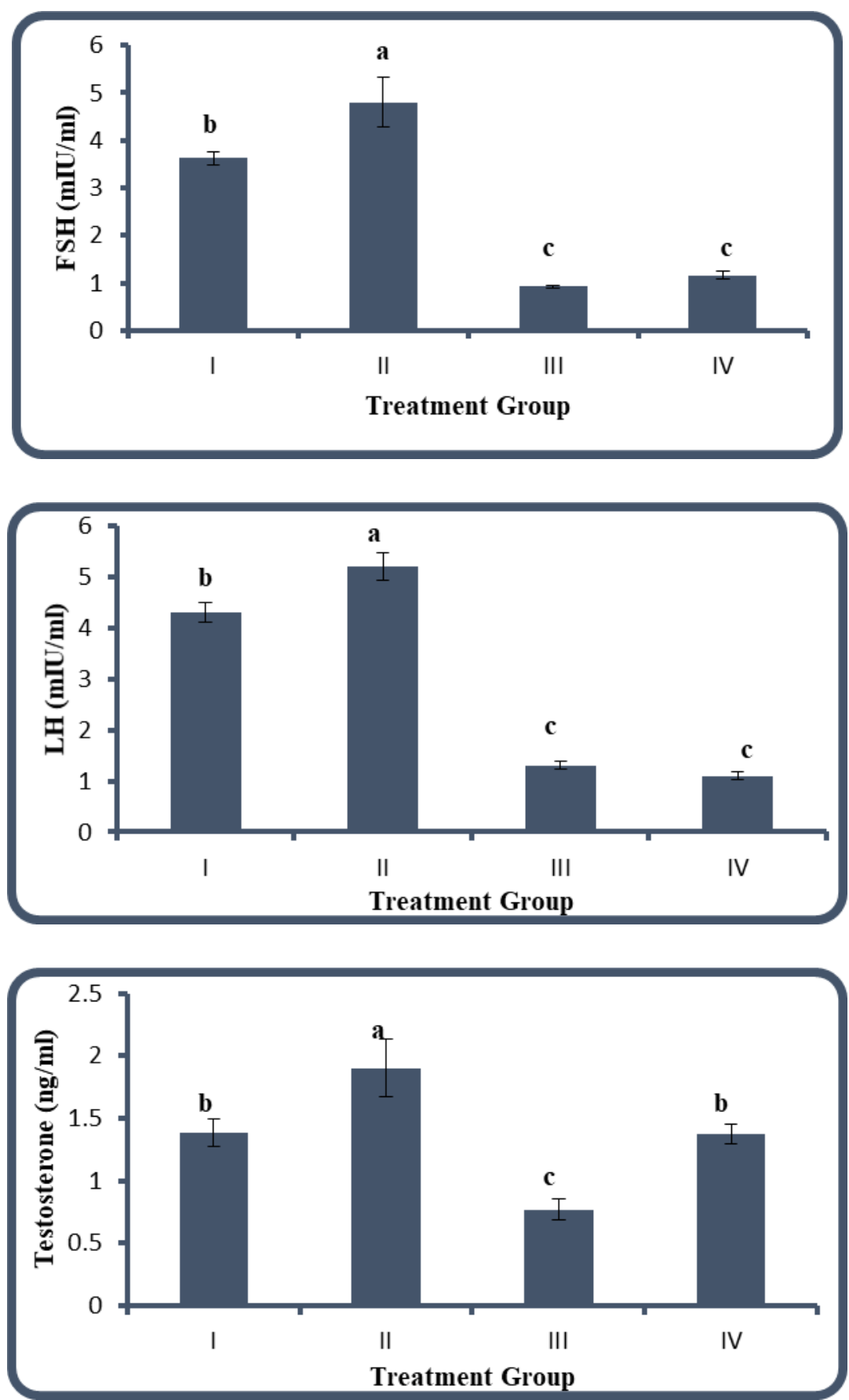

Fig. 4.Blood concentrations of FSH, LH and testosterone in experimental groups of adult albino rats exposed to Chlorfenapyr (180 mg/kg b.w), Quinoa seeds (30\% of basal diet), and their combination for 28 days. Bars with the different letters are significantly different at $(p<0.05)$. Values are expressed as means $(5$ rats $) \pm$ standard error (SE) 

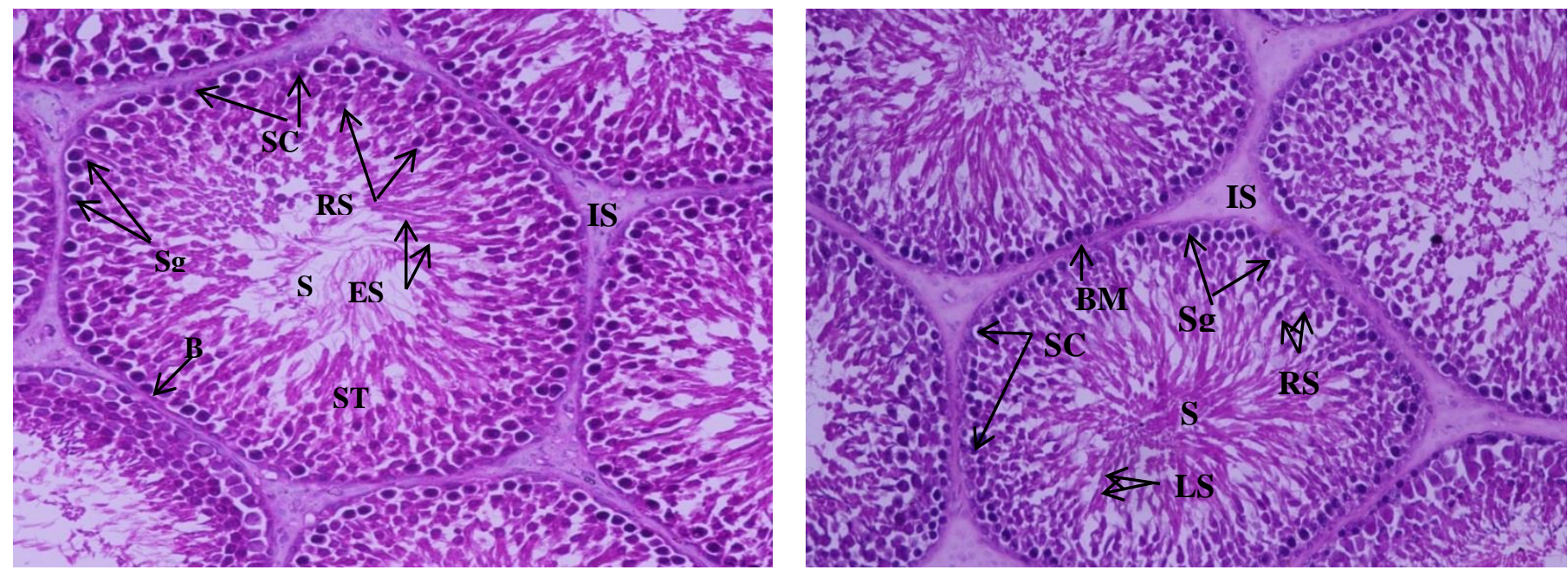

Fig. 5. Photomicrographs of rat testis sections from control on the right side and from group II on the left side. Normal shape of seminiferous tubules (ST) with normal internal spaces (IS) and Leydig cells. Ordinary arrangement of spermatogonia $(\mathrm{Sg})$ and Sertoli cells (SCs) resting on intact basement membrane (BM). Typical structure of primary spermatocytes (Ps), round (RS) and elongated spermatids (ES), and late- stage sperms (S).The number of mature sperms in the left. H\&E staining method, $(\times 400)$
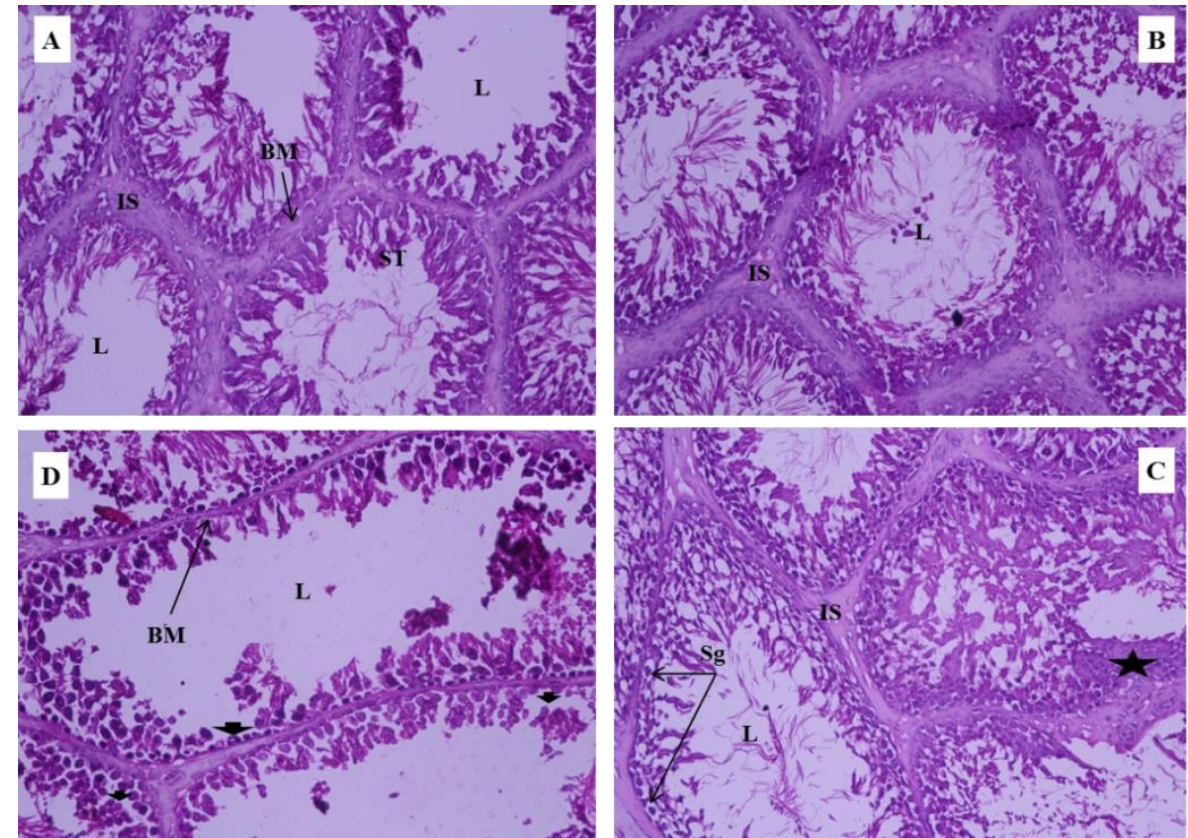

Fig. 6. Photomicrographs of Chf treated rat testis sections. Degenerated ST, with abnormally oriented SCs, wider IS with changing in Leydig cells number and structure (A, B), vacuolated cytoplasm of Sg, disrupted BM (C). Some ST presents many exfoliated cells (star), C, with few or no sperms (D). H\&E staining method $(\times 400)$ 


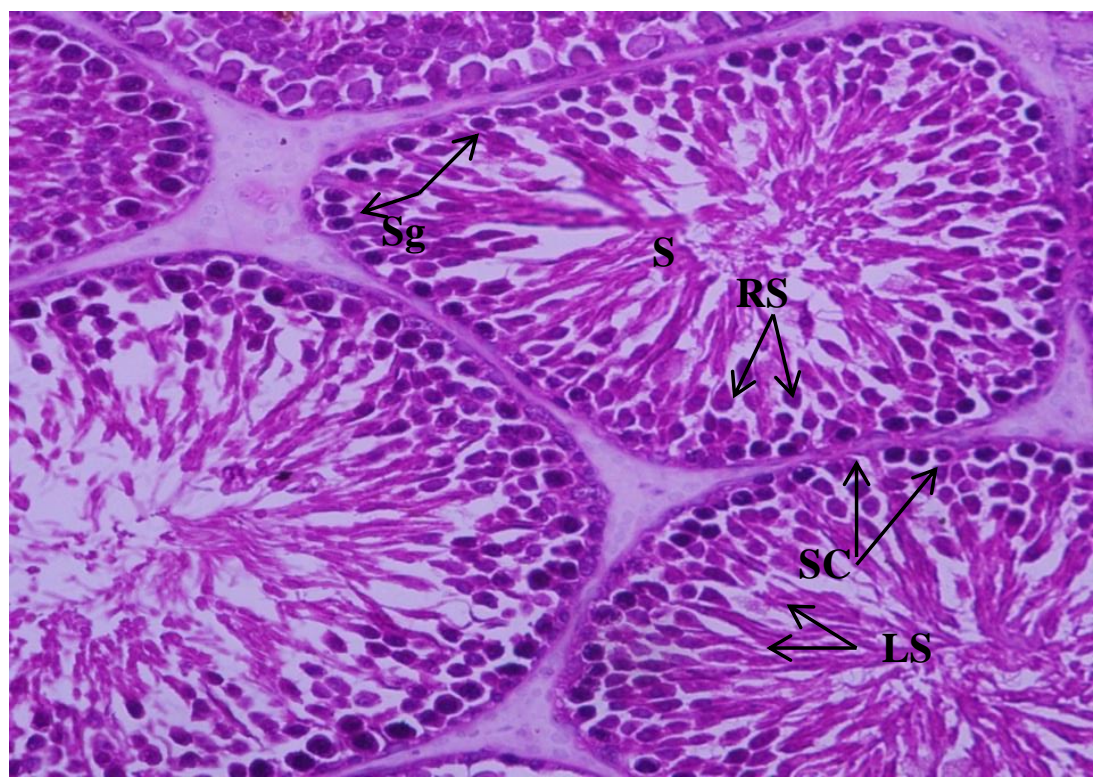

Fig. 7. Photomicrographs of Chf + QS treated rat testis section showing recovery for almost the pathological features which induced by Chf treatment, with normal seminiferous tubules and complete spermatogenesis. H\&E staining method $(\times 400)$

\section{CONCLUSIONS}

This study was carried to investigate the toxic effects of $180 \mathrm{mg} / \mathrm{kg}$ b.w/day chlorfenapyr on the reproductive system and the fertility of male rats after oral exposure for 28 days and the role of quinoa seeds consumption in alleviating these hazardous effects. Results showed that Chf induced harmful effects on the fertility indices such as relative reproductive organs weight, sperm characteristics parameters, sex hormones levels, and the histological architecture of rat testis. Also, the results revealed the important role of QS in reducing those changes and improve the fertility of the male rats, so the present study recommend the daily consumption of QS in our diet to improve our health and our fertility.

\section{REFERENCES}

Adamkovicova, M., R.Toman, M. Martiniakova, R. Omelka, R. Babosova and V. Krajcovicova. 2016. Sperm motility and morphology changes in rats exposed to cadmium and diazinon. Reproductive Biology and Endocrinology, 14(1).42.

Addor, R., T.Babcock, B. Black, D. Brown, R. Diehl and J.Furch. 1992.Insecticidal pyrroles: Discovery and overview: ACS Publications.

Ahmad, L., A. Khan and M. Z.Khan. 2012. Pyrethroidinduced reproductive toxico-pathology in non-target species. Pakistan Veterinary Journal, 32(1).
Alaa-Eldin, E. A., D. A. El-Shafei and N. S. Abouhashem. 2017. Individual and combined effect of chlorpyrifos and cypermethrin on reproductive system of adult male albino rats. Environmental Science and Pollution Research, 24(2): 1532-1543.

Albers, P. H., P. N.Klein, D. E.Green, M. J. Melancon, B. P.Bradley and G.Noguch. 2006. Chlorfenapyr and mallard ducks: Overview, study design, macroscopic effects, and analytical chemistry. Environmental Toxicology and Chemistry: An International Journal, 25(2): 438-445.

Alghamdi, E. S. 2018. Protective effect of quinoa (chenopodium quinoa willd.) seeds against hypercholesterolemia in male rats. Pharmacophore, 9(6): 11-21.

Babazadeh, M. and G.Najafi. 2017. Effect of chlorpyrifos on sperm characteristics and testicular tissue changes in adult male rats. Paper presented at the Veterinary Research Forum.

Badawy, M. E., M. S.Mahmoud and M. M. Khattab. 2020. Residues and dissipation kinetic of abamectin, chlorfenapyr and pyridaben acaricides in green beans (phaseolus vulgaris 1.) under field conditions using quechers method and hplc. Journal of Environmental Science and Health, Part B:1-8.

Chitra, K., E. Manogem, Y.Vardhanan Shibu, C.Sebastian and K. Jayakumar. 2011. Testicular and epididymal toxicity of carbaryl in spraguedawley strain rats. Journal of Advanced Laboratory Research in Biology, 2(2): 30-34. 
Choudhary, G. K., S. P.Singh and M. Batra. 2017. Ameliorative effect of rhizome powder of gandhpaalasi (hedychium spicatum) in indoxacarb intoxicated wlh cockerels. Indian Journal of Veterinary Research (The), 26(2): 37-41.

GenericDrury, R. and E. Wallington. 1980. Carelton's histology technique, 5th edit: Oxford University Press, Oxford, New York, Toronto.

El-Kashoury, A. A., A. F. Salama, A. I.Selim and R. A.Mohamed. 2010. Chronic exposure of dicofol promotes reproductive toxicity in male rats. Life Sci J, 7(3): 5-19.

El-Kewawy, H. a. and G. Morsy. 2019.Beneficial role of quinoa and nigella sativa seeds as antihyperuricemia in rats. Bulletin of the National Nutrition Institute of the Arab Republic of Egypt, 53(1):62-84.

Farag, A. T., A. F.El-Aswad and N. A.Shaaban.2007. Assessment of reproductive toxicity of orally administered technical dimethoate in male mice. Reproductive Toxicology, 23(2):232-238.

Hafez, E. 1970. Rabbits. Reproduction and breeding techniques for laboratory animals:273-315.

Hafez, L. 2018. Chemical and biological evaluation of some products from quinoa-based blends for celiac disease. Alexandria Journal of Food Science and Technology, 15(1): 23-34.

Han, S.-K., S.-R. Yeom, S.-H.Lee, S.-C.Park, H.-B.Kim and Y.-M.Cho.2019. A fatal case of chlorfenapyr poisoning following dermal exposure. Hong Kong Journal of Emergency Medicine, 26(6): 375-378.

Ikpeme, E., O.Udensi, U. Ekaluo, E. Uyoh, B.Asuquo and F. Udoh. 2007. Effect of crude extract of carica papaja seeds on the reproductive efficiency of male albino rats. Global Journal of Pure and Applied Sciences, 13(3): 365-368.

Jancurová, M., L.Minarovičová and A.Dandar. 2009. Quinoaa rewiev. Czech Journal of Food Sciences, 27(2):71-79.

Kang, C., D. H.Kim, S. C.Kim and D. S.Kim. 2014. A patient fatality following the ingestion of a small amount of chlorfenapyr. Journal of emergencies, trauma, and shock, 7(3). 239.

Khalaf, A. A., H. A. Ogaly, M. A.Ibrahim, A. A. Abdallah, A. R. Zaki and A. F.Tohamy. 2021. The reproductive injury and oxidative testicular toxicity induced by chlorpyrifos can be restored by zinc in male rats. Biological trace element research: 1-9.

Khushboo, M., M. K.Murthy, M. S. Devi, S.Sanjeev, K. S.Ibrahim, N. S. Kumar. 2018.Testicular toxicity and sperm quality following copper exposure in wistar albino rats: Ameliorative potentials of 1-carnitine. Environmental Science and Pollution Research, 25(2):1837-1862.

Kumar, A. and M.Nagar. 2014. Histomorphometric study of testis in deltamethrin treated albino rats. Toxicology reports, 1:401-410.
Kumar, N. and A. K. Singh. 2015.Trends of male factor infertility, an important cause of infertility: A review of literature. Journal of human reproductive sciences, 8(4). 191.

Lonare, M., M.Kumar, S. Raut, A. More, S. Doltade and P.Badgujar. 2016.Evaluation of ameliorative effect of curcumin on imidacloprid-induced male reproductive toxicity in wistar rats. Environmental Toxicology, 31(10): 1250-1263.

Lutz, M. and L.Bascuñán-Godoy. 2017. The revival of quinoa: A crop for health. Superfood and Functional Food-An Overview and its Utilization to Processed Foods (V. Waisundara, M. Shiomi, Eds.) In Tech Open:37-54.

Menkveld, R., C. A.Holleboom and J. P.Rhemrev. 2011.Measurement and significance of sperm morphology. Asian journal of andrology, 13(1). 59.

Paśko, P., P. Zagrodzki, H.Bartoń, J. Chłopicka and S. Gorinstein. 2010. Effect of quinoa seeds (chenopodium quinoa) in diet on some biochemical parameters and essential elements in blood of high fructose-fed rats. Plant Foods for Human Nutrition, 65(4):333-338.

Queiroz, E. K. R. d., and W. Waissmann. 2006. Occupational exposure and effects on the male reproductive system. Cadernos de Saúde Pública, 22(3): 485-493.

Rand, G. M. 2004.Fate and effects of the insecticide-miticide chlorfenapyr in outdoor aquatic microcosms. Ecotoxicology and environmental safety, 58(1): 50-60.

Robb, G., R.Amann and G. Killian. 1978. Daily sperm production and epididymal sperm reserves of pubertal and adult rats. Reproduction, 54(1): 103-107.

Saber, T., R.Abd El-Aziz and H.Ali. 2016.Quercetin mitigates fenitrothion-induced testicular toxicity in rats. Andrologia, 48(5):491-500.

Saxena, S., L.Shahani and P. Bhatnagar. 2017. Hepatoprotective effect of chenopodium quinoa seed against ccl4-induced liver toxicity in swiss albino male mice. Asian J. Pharmaceutical Clin. Res, 10:273276.

Sdeek, F. A., A. R.Morsy, H. M.Arafa and E.Kamel. 2016.Dissipation behavior of chlorfenapyr on citrus and tomato in egypt. International Journal of Innovation and Applied Studies, 18(1).131.

Shaheen, B. and A. M. Yousafzai. 2017. Ameliorative effects of garlic (allium sativum 1.) against chlorpyrifos intoxication on lipid profile and liver enzymes of male new zealand rabbits (oryctolagus cuniculus). Journal of Entomology and Zoology Studies, 5(3):1573-1578.

Sharma, P., A. U. Huq and R.Singh. 2014. Cypermethrininduced reproductive toxicity in the rat is prevented by resveratrol. Journal of human reproductive sciences, 7(2). 99.

Sleem, F., M. M.Elalfy, A. A. Abd Allah, M. F.Hamed and M. Abomosallam. 2019. Developmental and ultrastructure toxicity of greenhouse insecticide chlorfenapyr in rat fetuses. 
Slott, V. L., J. D.Suarez and S. D.Perreault. 1991. Rat sperm motility analysis: Methodologic considerations. Reproductive Toxicology, 5(5): 449-458.

Treacy, M., T. Miller, B.Black, I. Gard, D.Hunt and R.Hollingworth.1994.Uncoupling activity and pesticidal properties of pyrroles: Portland Press.

Valencia-Chamorro, S. 2003.Quinoa. Inencyclopedia of food science and nutrition (Vol. 8, pp. 4895-4902): Academic Press, Amsterdam.

Vilcacundo, R., and B.Hernández-Ledesma. 2017.Nutritional and biological value of quinoa (chenopodium quinoa willd.). Current Opinion in Food Science, 14:1-6.
Wahba, H. M. A., M. H. Mahmoud and H. F.El-Mehiry. 2019. Effect of quinoa seeds against cisplatin toxicity in female rats. Journal of Advanced Pharmacy Education \& Research| Jul-Sep, 9(3). 47.

Wang, Y.-X., Q.Zeng, Y.Sun, P. Yang, P. Wang and J. Li. 2016.Semen phthalate metabolites, semen quality parameters and serum reproductive hormones: A crosssectional study in china. Environmental Pollution, 211: 173-182.

\section{الملخص العربي}

\section{بذور الكينوا لتخفيف سمية مبيد الكلورفينابير لخصية الجرذان}

نادية علي حامد

التجرببية أربعة أسابيع. تم ذبح الجرذان وتم جمع عينات من سيرم الدم والحيوانات المنوية والأعضاء التتاسلية للدراسات البيوكيميائية والنسيجية. أوضحت النتائج أن الحيوانات التي تم معاملتها بـ Chf أظهرت ترهل الخصيتين وزيادة الوزن النسبي للخصية. وقد ارتبط هذا التأثير بانخفاض عدد

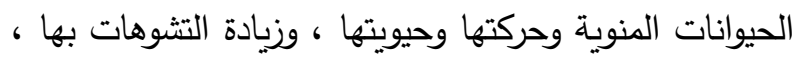
وانخفاض مستوى الهرمونات الجنسية في الدم (P P) ( P.05). من ناحية أخرى ، أظهرت بذور الكينوا تحسنًا في جميع Chf التقديرات تقريبًا وخفقت من جميع التأثيرات الخطرة لمبيد لحنيد ، والتي تم تأكيدها من خلال الفحص النسيجي للخصية. لذلك ، يمكننا تشجيع استهلاك الكينوا للتغلب على مشاكل السمية والعقم التي تظهر نتيجة التعرض لمبيدات الآفات وغيرها من المواد السامة.

الكلمات المرشدة: كلورفينابير - سمية الخصية -

$$
\text { الجرذان - كينوا }
$$

ينتمى مبيد كلورفينابير(Chf) لمجموعة جديدة تسمى

pyrroles المهلجنة ، وتستخدم على نطاق واسع في مصر. أوضحت الدراسات وجود بعض الآثار السلبية لبعض المبيدات على الجهاز التتاسلي الذكري على نطاق واسع. في السنوات الأخيرة ، ازداد استخدام الأعشاب الطبية للحد من سمية مبيدات الآفات ؛ واحدة من هذه الأعشاب هي بذور الكينوا (QS) ، والتى تحتوي على كمية عالية من البروتين والفيتامينات والمعادن. استهدفت الدراسة الحالية الى تقييم تاثير QS على الفئران المعرضة لـ Chf. تم تقسيم عشرين فأرا إلى أربع مجموعات. تم إطعام المجموعة (I) كنترول على النظام الغذائي الأساسي فقط ، المجموعة (II) بS بنسبة

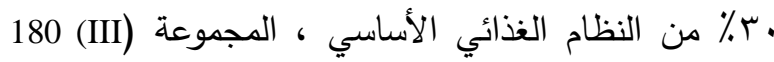

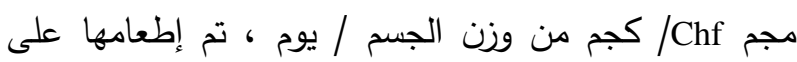
النظام الغذائي الأساسي فقط والمجموعة Chf ( (IV) عند

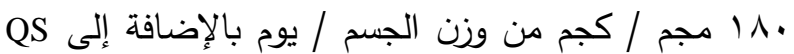
بنسبة . ץ\% من النظام الغذائي الأساسي حيث كانت الفترة 